\title{
Council, Star Chamber, and Privy Council under the Tudors
}

\section{The Star Chamber}

$\mathbf{I}^{\mathrm{N}}$

$\mathrm{N}$ the last number of this Review an attempt was made to indicate the nature of the king's council in Tudor times before its clear differentiation into privy council and council in the star chamber. We have now to continue the history of the parent stem and to discuss the personnel, organization, and functions of the council in the star chamber. The delimitation of the two councils, which had a common origin and continued to have much that was common in personnel and in function, is, however, so difficult that it is advisable to begin with the simplest elements in the problem and to point out that primarily the phrase star chamber indicates neither a council nor a court, but simply a building. Chamber itself is misleading; for while we now talk about a house containing several chambers, it was possible in the sixteenth century to talk about a chamber containing several houses, and the star chamber was a three-story building with at least three rooms and a kitchen in it before the end of the Tudor period. ${ }^{1}$ There was the large room generally indicated by the words star chamber when used alone; there was the inner star chamber; and there was a third room on the east side overlooking the river, in which suitors could wait and distinguished visitors like Henrietta Maria could watch the course of proceedings. ${ }^{2}$ When the council sat as the court of star chamber it

1 Sce the riews in J. T. Smith's Antiquities of Westminster (1807) reproduced in Hawarde's Star Chamber Cases, ed. Baildon (1894).

t Hawarde, p. 39 : "It was also ordered by the Lord Keeper that the empty room at the east side of the court of late enclosed with a door shall be reserved for men of good account in the country and for gentlemen towards the law, and shall not be plagued with base fellows and women or other suitors, as it has been' (13 February 1595/6); and ibid. p. 250 (20 Norember 1605), "The plaintiff objected against this order two otherorders (one taken in the Inner Star Chamber and the other at the Lord Chancellor's house) which countermanded that order. But the Lord Chancollor disallowed them, and aid to the practisers that they pick their clients' purses by these house and chamber orders; "for" said he "you are all honest gentlemen, but I believe never a word you say when you move me at roy house or in the chamber"; and as it was said by the Attorney-General, "I find," said he, " that God doth assist the judge 
always sat in the larger room, but it frequently sat as a privy council in the inner star chamber.

The original star chamber was built between 1340 and 1350 near the Receipt of the Exchequer as a council chamber ${ }^{1}$ in addition to that exchequer chamber in which the council had previously sat for financial and other business; but it is almost certainly an error to regard it as the only council chamber which could be described as 'near the Exchequer'." Whether it originally contained more than one room is not known, but as early as Richard III's reign we read of the king summoning all the judges to consult with him in interiori Camera Stellata, ${ }^{3}$ and considerable additions to it were nade in Wolsey's time about 1518. Appropriately enough he employed fines levied before him there to 'lengthening and making of the Sterre chamber at Westminster ', ' which only disappeared with the great fire of 1834. Possibly some reconstruction had been necessitated by the fire of 1512, since which no English sovereign has lived in Westminster Palace, though, as Stow remarks, 'the great hall, with the offices near adjoining, are kept in good reparations, and serveth as afore for feasts at coronations, arraignments of great persons charged with treasons, keeping of courts of justice, \&c.'s

This star chamber was the frequent if not the regular place

in his judgement seat but not in his chamber ".' Here 'chamber ' seems to distingaish the inner star chamber from the court of the star chamber; but Hudson, in Hargrave's Collectanea Iuridica, ii. 41, refers to the two sworn clerks of the star chamber, "the one for the decrees of open court, the other for ordinary course '. In Letiers and Papera of Herry VIII (iv. 3258) is a reference to "the length of the table in the inner chamber of the Star Chamber'. Henriette Maria apparently used the third room when she followed the proceedings in Pell v. Bagg (Rushworth, ii. 303). Besides itu clerks the atar chamber had its domestic staff, an usher, steward, butler, and kitchen officials; and the dinners served there were regular state functions.

1 A number of references to the building acconnts are collected in Baildon's edition of Hawarde, pp. 453- 84 . Stow mentiong other buildings of that decade, viz. the reconstruction of St. Stephen's and the construction for the canons, \&c., of honaes atretching from the Receipt of the Exchequer to the river, and later the weigh-house between the clock-house and the wool steple. In Henry VIII's reign the clerk of the wool staple was also clerk of the house of commons.

In Leadam and Baldwin's Select Cases before the King's Council (Selden Soc.), p. 91, an exchequer chamber case is assumed to be a star chamber case because it was heard en la chandre joignante a meone leschequier. But in every real star chamber case in the volume the star chamber is specifically indicated eo nomine; and in 1493 the judges, in commenting on Stat. 31 Edward II, c. 12, which uses the phrase en ascun chambre du conseil joust lexchequer, identify it with le Eschiquier chambre (Y ear Books, Tottel's ed., 8 Henry VIf, Pasch., fo. xiii.).

I Ibid 2 Richard III, Mich., fo. ix $b$.

- Letters and Papers of Henry VIII, ii. 1476; cf. ibid. no. 3741, ' a new house adjoining the Sterred Chamber'. Hudson, loc. cil., ii. 64, says 'Dr. Allan and Christopher Plummer in 9 Henry VII (1517-18) were fined 000 marks, which was ordained to be employed for the new building of those rooms which are now from the Court of the Star Chamber to the bridge in the palace', i.e. northwardn to where the clock tower now stands.

- Surcey, ed. Thoms, p. 174. 
in which the council met during the fifteenth century to discharge most of its multifarious functions, deliberative and administrative as well as judicial. Just as the chancellor and his colleagues in the virtue of 31 Edward III, c. 12, could hear cases of error from the exchequer in any council chamber, so the council in the star chamber could deal with any kind of council business. There may have been some distinction, which the records da not reveal, between what the council did in the inner and in the outer star chamber; but I have found no specific reference to the two chambers before 2 Richard $\Pi I$, and long enough after that the star chamber remained simply, as Mr. Loadam has said, a locus in quo. ${ }^{*}$ This fact led to confusion before the end of the Tudor period. For example, the circumstance that the counsellors told off to hear poor men's causes undoubtedly sat at one time in the star chamber ${ }^{2}$ enabled Sir Julius Caesar and other masters of requests to contend that the court or council of requests had been the real king's council ; and the fact that the council of the fourteenth and fifteenth centuries had sat in the star chamber enabled Mill and other clerks of that 'court' at the end of the sixteenth to maintain that the council whose records they kept was the only real council of state in England, the privy council being in their eyes merely 'a private board, although the most honourable in the world '.

The term star chamber has, however, become so exclusively identified with one particular aspect of the council's activity in

1 Slar Chamber Cases, ii, p. xiii.

- The council had repeatedly been roquired by periisment and resolved during the fifteenth century to give preference to poor men's suits (Rot. Parl. iv. 201, v. 108; Nicolas, iii, pp. rix, 140-52, 214-20 ; iv. 60-3), and we have already notod Harington's appointment as clerk of the council for that purpose. The counsellors detuiled for that duty are said to have sat in the white hall in Henry VIIs reign, but other cases, even cases of treason and heresy, Fere also tried there (my Henry. VII, i. 209-10; Hell, Chron, p. 826); and it is not untill 1519 that wo havo the definite record appointing eight counsellors ' to hear the causes of poor men depending in the sterred chamber' and to 'sit in the white hall in Westminster, where the said suitors shall resort' (Letters and Papers, iii. 571 ; the document is printed in full in Leadsm, Requests, pp. Ixrri-ii). Cenesar remarks (Leadam, Court of Requests, p. Ixri), 'Some judges of this court have from time to time till 1 Elizabeth set alternis vicibus as judges in the Btarchamber'. It would be clearer to say that these 'judges ' were members of a yet andivided council which transacted its undivided business in its usual counoil room, the star chamber. The term court was not commonly applied either to the council in the star chamber or to the council in the white hall until the middle of the eirteenth century. There was 'counsel for requests' attendant apon the hing as well as connsel in the white hall. Often this 'counsel' was a oingle porson. Dr. Wolman is so nominated in the Eltham ordinances, and Sir Julius Caesar speaks of 'my ordinary place of Master of Requests attendant upon her [Flizabeth's] person '; he had been appointed extraordinary Haster of Requests four years entier (Leadam, Requests, pp. xii, sxiv n.). The form of the word requestae (instead of the requioitiones of Richard III's appointment) appears to have been borrowed from France; Coke, indeed, ascribes the whole 'oourt' to imitation of France (Institutes. iv, ch. O).

Hadson, loc. cil., ii. 62. 
that place that it may be well to illustrate some of the other functions there discharged. It was in the star chamber that on the day after the end of each term a full assembly of councillors, judges, justices of the peace, and others was held and addressed by the lord chancellor, sometimes by the sovereign. ${ }^{1}$ The usual topic was an exhortation about the administration of justice and maintenance of law; but any other might be introduced, sometimes in Elizabeth's reign 'such things as herself, if tym had permitted, meant to have uttered in parliament ', 2 the state of Ireland, Essex' rebellion, ' the peace of her Church', and the assessment of taxation; ${ }^{4}$ and Wolsey and James $I$ were as assiduous and as versatile but not so happy as Elizabeth in these star chamber addresses. ${ }^{5}$ In the star chamber, too, was taken every half-year the assay of the mint or trial of the pyx, after its removal from the Tower. ${ }^{8}$ The cases of Anne Boleyn and Catherine Howard were considered in the star chamber, although they were necessarily tried elsewhere. ${ }^{7}$ The Scottish prisoners taken at Solway Moss were brought before the star chamber ; ${ }^{8}$ musters were returned thither $;^{\theta}$ measures of wine were tested there ${ }^{10}$ and orders issued to regulate municipal government. ${ }^{11}$ The star chamber was in fact the room in which most decrees and orders in council were adopted, and it is mistaking the accident for.the essence to describe Mary's and Elizabeth's measures regulating the printing press as star chamber decrees instead of orders in council.

In the star chamber, too, Henry VIII discussed Tyndale and Joy's translation of the bible on 25 May 1530; there in 1538 English bibles were ordered for use $;^{12}$ and a special court was set up under the statute of Proclamations, with Cranmer at its head instead of the lord chancellor, to deal in the star chamber with

\footnotetext{
1 Henry VIII preferred to address parliament, James I and Charles I the star chamber.

- Wilbraham, Journal (Camden Soc. Miscell., 3rd ser., vol. x), p. 12.

2 Ibid. pp. 30-2. - Ha warde, ed. Baildon, pp. 101-2.

- Hall, Chron., pp. 644, 742 ; James I, Political Works, ed. MoIlwain, pp. 326-45 ; Scofield, pp. 57-9.

- It was held in 1526 at the Tower (Letters and Papers, Iv. 2338), but in 1527 and afterwards in the star chamber (ibid. IV. 3590, 6395; VII. 1332; II. 45 ; III. i. 1150 ; Egetion Papers (Camden Soc.), pp. 186-8; Hawarde, p. 38).

- Letters and Papers, x. 792, xvi. 133. The jurisdiction of the atar chamber did not extend to treason or felony, unless the Crown was content to treat the case as a 'trespass' and not a capital charge (Hudson, ii. 63); 'trespass' was still used where we thould aay 'misdemeanour' (cf. Maitland, Lectures, p. 230). In 1533. however, a parliamentary bill was drafted, but went no further, to give the star chamber jurizdiction over murders in Wales and its marches (Letters and Papers, vi. 1381 [3]).

- Letters and Papers, xrii. 1223; Wriothesle5, Chron. i. 162-3.

- Lellers and Papers, iii. 3683 [7].

10 Ilid. ii. 3972.

11 e. g. Bererley in 1535 (Lellers and Papers, ix. 002).

12 Hall, Chron. p. 771; Wriothesley, Chron. i. 74.
} 
offenders against proclamations 'concerning any kind of heresies'.1 In February 1591 a peerage case was ordered to be tried in the star chamber 'by such of their Lordships and others as are therunto appointed by her majesty'.' In 1534 the lords, after passing the bill against the Nun of Kent, agreed that Sir Thomas More and others named in it should be heard 'coram Dominis in regio senatu secus nuncupato the Sterred Chamber'; ${ }^{3}$ and in 1515 a lords' and commons' committee met there to discuss the carrying over to the next session of bills not passed before the prorogation." It was in the star chamber that a committeo of lords and commons made the first breach in the defences of the church against the Reformation in December 1529. ${ }^{5}$ The star chamber was in fact frequently used for commons' committee meetings, and it was in the star chamber that a committeo reviewed in December 1640 the sentences against Prynne, Burton, and Bastwick. 'It happened', writes D'Ewes to his wife, 'by a mere casualtie that our first sitting upon this business was in the Starre-Chamber, wheerein I noted God's wonderfull Providence, that wee should sitt in that Court wheere their bloudie sentences had passed against them, to judge those sentences.' 6

When all these things, and more, could be done in the star chamber, how came star chamber to have a specific meaning excluding most of these functions ? The plausible answer is that the so-called Star Chamber Act of 1487 (3 Henry VII, c. 1), which was long regarded as the original and sole statutory foundation of the court, and is still treated as the most important incident in its history save its abolition, gave the star chamber its predominant characteristic. It may be easier to follow the trend of my argument if $I$ premise at once that, so far as I can see, the act. of 1487 had little or nothing to do with the star chamber, and that its provisions are inconsistent with what we know of the personnel, the practice, and the procedure of that court. It is well enough known that the words star chamber do not occur in the act on which it was supposed to rest; less familiar are the facts that the words occur neither in the judges' interpretation of the act in $1493^{7}$ nor in the act of $1529^{8}$ which praised and amended that of 1487 , and that for at least half a

31 Henry VIII, c. 8; Leadam, Slar Chamber Cases, ii, pp. rix-xx, 225, 277; Wriothealey, Chrom i. 130 . Lambert had been tried in November 1538 for heresy in the white hall (Hall, Chron. p. 826). Bonner's sentence of deprivation was confirmed in the star chamber in February 1550 (Wriothesley, Chron. ii. 33).

- Acts Priv. Coun 1590-1, p. 251.

' Lords' Journals, i. 72.

- Ibid. i. 45, 46, 47.

s Hall, p. 767.

- D'Ewes, Atubiogr. ii. 251-2.

' Year Books, Tottel's ed., 8 Henry VII, Pasch., fo. xiii ; my Henry VII, ii. 67.

- 21 Henry VIII, c. 20. 
century after that date it does not seem to have occurred to any one to see any connexion between 3 Henry VII, c. 1, and the star chamber.

The first point to explain is how the words 'camera stellate' and 'star chamber' came to appear on the margin of the roll of parliament, whence they have got into the printed Statutes of the Realm. The parliament rolls are the original authority for parliamentary statutes down to Henry VII's reign. 'They contain procedings as well as enacted petitions, and down to 8 Edward IV the statutes are extracted from the parliament rolls and enrolled in a separate collection of statute rolls, of which a transcript was sent to the exohequer and is cited as $\mathrm{Lib}$. Scacc. ${ }^{2}$ Gradually during the Tudor period the proceedings dropped out of the parliament roll, which became a mere statute roll, while the proceedings were entered in journals, from 1510 of the lords, and from 1547 of the commons. The original statute roll cessed to be made up, and none is known after 1468. There are, however, two contemporary manuscripts which look like transcripts from a statute roll, one, Petyt MS. (Inner Temple), coming down as far as 1487, and the other, Bodleian MS. 3701 (Hatton 110), continuing nearly to the end of 11 Henry VII, and there is also the Lib. Scacc. None of these, however, nor Caxton's contemporary print, has any reference in text or in margin to star

1 Earlier editions of the statutes, apert from the king's printer's contemporary and official publication of the statutes of each successive parliament, were private ventares by editors who reprinted previous editions, generally omitting statutes which had expired and others which the editors regerded as private acte; but they did not go to the manuscripts either of the rolls or the original acts for their tert. Henoe the title of 3-Henry VII, c. 1, is varied at will by differont editors in their various editions. The Statutes of the Realm take the text of 3 Henry VII, c. 1, from the roll and also the marginal headings without noting that the latter are in later hands than the text; the editors also modernized 'eucthority' into 'authority' in the marginal heading, but not 'auctorite' in the text.

- In the fifteenth century it was referred to the judges to determine which of the proceedings of parlisment were statutes and should therefore be proclaimed, and which were not; all, however, were to be enrolled in chancery, a was the custom (Nicolas, iii. 22). A facsimile of a page of the Lib. Scace. is given in the Statutes of the Realm (ii. 477), and another of a membrane of the Statute Roll is given at p. 1 of the same volume. Both are reproduced in 4 ppendix to Record Comm. Reports, 1800-18.

- Statutes of the Reaim, ii. 499, 524; Record Commission, Procedings, 1800-12, p. 179. The Hatton MS. was made for the Serjeant Piggott who occurs in Wolsey's well-known letter quoted below, p. 528. It ends in the middle of a sentence from 11 Henry VII, 0. 27. It resembles the Petyt MS, but accosionally varies the order of the acts, e. g. c. 11 of 3 Henry VI is c. 15 in the Piggott MS., which also gives an expired act omitted in Petyt. Both are in French to the end of 3 Henry VII. With 4 Henry VII the Piggott MS. bogins to be in Finglish and also gives chapter headinga as in the printed acts, from which it was probably transcribed after 3 Henry VII. The Lib, Scacc. is in English from 1487. The inference is that down to the end of 3 Henry VII there was a statute roll made up in French, though the manuacript does not exist after 1483 , and that after 1487 the king's printer's text took the place of the Statute Roll. 
chamber. Where and how, then, did the misleading marginal titles 'pro camera stellata' and 'an acte geving the Courte of Star-chamber aucthority to punnyshe dyvers mydemeanors ', \&c., come to be on the parliament roll ?

This problem should probably not be studied in isolation. A long line of legal writers, Nathaniel Bacon, Blackstone, Dwarris, Hardcastle, Craies, have discussed the question when it became the practice to give a distinct title to each chapter or act in a statute $;^{1}$ and they have most of them assigned different dates varying from 11 Henry VII to 5 Henry VIII. Not one is really correct because the question is not properly stated. There were no contemporary chapter headings made on the parliament roll before the sixteenth century and none of any date on the statute roll. But as soon as the printing of statutes begins we find brief headings supplied to each printed act, though without any enumeration. Caxton gives them, consisting generally of one word only, for all the acts he prints of the parliaments of 1485-9; and they gradually become more elaborate under the hands of successive king's printers, though remaining absent from the enrolments in chancery from which the statutes were printed. ${ }^{2}$ These authoritative editions, printed by the king's printer from a copy supplied by the lord chancellor, and paid for by the Crown, became in time the texts which even lawyers and lawgivers cited in place of the rolls. Gradually the convenience of citation led to acts being not merely entitled but enumerated and cited by their numbers instead of merely by the place at which they were passed. ${ }^{3}$ For the statute of Westminster $\Pi \Pi$ we get 13 Edward I, stat. 1, divided into fifty chapters, for the statute of Winchester we get 13 Edward I, stat. 2, and for the statute of Merchants 13 Edward I, stat. 3, while the writ circumspecte agatis is made into 13 Edward I, stat. 4. Some at least of Edwrard I's statutes were 'made' in the sixteenth century. For, as always happens, men were not content

1 In Caxton each act begins simply with 'item' and is an itom in the statnte; sometimes the beginning is not even marked by a now paragraph, and it never is on the Statute Roll. Francis Becon, Reading upon the Statute of Uses, 1648, p. 26, gives 5 Henry VIII as the date.

- Letters and Papers of Henry VIII, new ed., I. i. 485 [4] : Warrant to the archbishop of Canterbury, Chancellor, to deliver to Richard Pynson, the king's printer, a true copy of the statutes lately passed in Parliement, that he may print them.' Cf. ibid. IIv. i. 1227, where John Husee writes on $7 \mathrm{July} 1059$ that the king's printer has delivered 1,500 copies of the statutes passed in the partiament of that year to the lord chancellor. There are frequent entries in the Lelters and Papers of royal payments for printing statutes, proclamations, \&a. Its control of the printing press was as useful to the Crown as its control of artiller;; and both arose from the ame cause: the Crown alone conld afford to finance the earliest presses.

- The regular holding of parliaments at IVestminster had increased the inconvenience of merely place-names for statutes, and the Piggott MS. written about 1500 begins to describe medieval acts in the modern form with 1 Edward III. In Henry VII's reign parliament itself begins regularly to refer to earlier statates by regnal sears, but chapter references to acts do not begin until a lnter period. 
to use their new style in the present and for the future, but applied it to the past with such vigour that in Serjeant Hawkins's edition of the Statutes at Large (1735) the 1225 reissue of Magne. Carta appears as Stat. 9 Henry III, co. $\mathbf{i}-x \times x$ vii.

So, at some uncertain date, probably not earlier than Elizabeth's reign, some lawyer or clerk attempted to bring the rolls of parliament up to date by inserting in the margin titles which the acts had not but presumably ought to have. The marginal headings from 1483 to the end of the century are in a late sixteenth-century hand, and so are those for the acts of 1 and 3 Henry VIII. But those for 19 Henry VII and 5 (if not 4) Henry VIII appear to be contemporary, and this may be the evidence for Francis Bacon's statement that chapter headings begin in 5 Henry VIII. These are, however, the annotations of a clerk and no part of the act of parliament. No greast harm was done as a rule by this posterior annotation, provided that we remember that these later titles have not only no legal, but no contemporary historical or philological value. ${ }^{1}$ But occasionally harm was done, and the marginal annotator of 3 Henry VII, c. 1, misled posterity so seriously that we must investigate at least the date of the annotation. Palaeographers are cautious, and do not quite agree whether the shorter Latin or longer English title is the earlier ; but neither is much earlier than 1550, and both may be considerably later. No printed edition, it may be remarked, has either of the two annotations before Pulton's edition of 1606, where one first appears in the margin, and his edition of 1618 , where the other first appears as a heading. The spellings 'aucthority' and 'star' chamber and the use of 'Courte' point in the same direction. Caxton has 'auctorite' and 'auctoryte', which were the regular forms till about 1650 . Then an ' $h$ ' is added, and by 1600 the ' $c$ ' begins to drop out; ${ }^{2}$ the final ' $\theta$ ' or ' $i e$ ' gave place to ' $y$ ' about the same time. 'Star' is equally rare before 1550 : 'sterret' appears in 1454 ; 'sterred chamber' 3 is the usual form in Henry VIII's reign, though 'sterre' and 'starre' are also found. 'Mydemeanors' for 'misdemeanours' I cannot evaluate.

We find, therefore, that, so far as the text of 3 Henry VII, c. 1, is concerned, its reference to the star chamber dates from the latter half of the sixteenth century. The same conclusion is reached from a study of later legislation and of political writers.

1 Thus in the New Eng. Dicf. this late sixteenth-century marginal note is cited under 1487, giving for that year the spelling 'authority' used by the eighteenth-century editor of the Rolls of Parliament. Fortunately this eighteenth-century spelling of 'authority' is not cited for 1487 s. v. 'authority', but o. v. 'misdemennour'.

- Crompton in 1594 has 'L'Authoritie des Courts', but he was writing in lew French, and not in English.

- This is the proper English for camera stellata, and is really conclusive against the fanciful Hebrew derivation. Chambers were generally known by their decoration, e. g. painted chamber, white chamber, green chamber all oocur frequently in the rocords. 
There are a number of statutes referring either to the act of 1487 or to the star chamber, but none connects the two before 5 Elizabeth, c. $9,{ }^{1}$ and that refers guardedly to 'the power or aucthoritoe given by Acte of Parliament in the tyme of Henry VII ${ }^{\text {th }}$ to the Lord Chancellor of England and others of the Kinges Counsell . . . to examine and punish Riottes, heinous Perjuries . . . which Lord Chancellor and others since the making of the saide Acte have mostly commonly used to hear and determyne such Matters in the Courte at West ${ }^{m}$. commonly called the Starre chamber'. The political writers tell the same tale. Sir Thomas Smith in $1565^{2}$ does not mention the 1487 act in his account of the star chamber, but attributes its augmentation to Wolsey. Before 1600, however, Camden and Lambarde are familiar with the connexion between 3 Henry VII, c. 1 , and the court ; ${ }^{3}$ a contemporary annotator of Crompton's L'Authoritie et Jurisdiction des Courts (1594) believes that that act was its foundation; and from that time onwards every writer feels bound to mention 3 Henry VII, c. 1, though all of them, who have any pretence to scholarship, denounce the absurdity of the theory, while they are puzzled to explain exactly what effect the act had upon the court. Maitland noted that Edmund Plowden (1518-85), a great common lawyer, was credited with the opinion that the star chamber derived all its legal authority from Henry's act, ${ }^{5}$ but the junior counsel who quoted him was overruled by the court. Plowden, however, begat the theory on which the long parliament abolished the star chamber.

History is very much of a palimpsest, and, having cleared the 1487 act of its later pseudo-star chamber accretions, we may proceed to examine its original character. We can do so best by contrasting the committee which it set up with the council sitting

1 There may be an earlier legislative reference to the supposed connexion. In a draft for 1533 of 'acts necessery to be made at this Parliament' (Letlers and Papers, vi. 1381) is a proposel that the chancellor with two judges may proced in all cases in the star chamber notwithstending the absence of the treasurer and others mentioned in previous aots. The proposel got no further; it was probably pointed out to the originator of the idea that it was unnecessary and mistaken. The ater chamber was the king in council in the star chamber, and no statutory requirement of a quorum in the king's conncil was permisuble. A quorum was often required by statuto when the officiating body was not technically the king in conncil, but a group of officials like those named in 3 Henry VII, c. 1, 21 Henry VII, c. 20, 25 Henry VIII, c. 2.

- De Republica Anglorum, ed. Alston, p. 117 ; see below, note 2, p. 820.

- Camden, Brilannia, ed. 1586, p. 63, ed. 1590, p. 107, ed. 1594, p. 112, ed. 1600, p. 141 ; Lambarde, Archeion, pp. $16.5-200$, dedicated to Sir Robert Cecil in 1591, but not published till 1635 . In 1086 Camden has nothing about the history of the court; in 1590 he has superiori seculo instiluia fuit; but not till 1594 has he any reference to Henry VII or parliamentary statute. He probably got it from his friend Lambarde, who seems first to have given literary currency to Plowden's theory.

- Manuscript note in the University College copy by Charles Hales, who has written the date 10 December 1594 on the title-page.

- Lectures on Const. History, p. 262. No reference is given, but it is obviously to the story in Hudson apud Hargrave, Collectanea Iuridica, ii. 50. 
in the star chamber. The committee sat in private, while the star chamber was a public court; the committeo had a rigid statutory quorum, the star chamber had none. The committee had a definite personnel, but was limited to no time or place; the star chamber had no definite personnel, but was fixed at Westminster and limited as a rule to term-time. ${ }^{1}$ Bills with which the committee dealt were to be put to the chancellor ; those heard in the star chamber were put to the king and council. The two duties specifically allotted to the 1487 committee by 21 Henry VIII, c. 20, which added the lord president to its number, were the fixing of prices of wines and the naming of sheriffs, both of them purely administrative functions, the latter of which was exercised not in the star chamber but in the exchequer or the exchequer chamber. ${ }^{3}$ The committee of 1487 is not known to have had a clerk or kept any records; the clerk of the star chamber was the senior clerk of the council, and its records are abundant. But in those records there has not yet been found a single case in which the adjudicators in the star chamber correspond with the personnel laid down by the act of 1487." The committe was probably bound by the judge's interpretation in 1493 of the act of 1487 to the effect that the chancellor, treasurer, and lord privy seal alone were judges of the court, and the other four members only assistants ; the star chamber certainly was not. It has long been admitted that, if 3 Henry VII, c. 1, referred to the star chamber, the star chamber never considered itself bound

1 Later on, when the confusion between the committeo of 1487 and the council in the star chamber had been made, the latter, as reported by Hudson, used the confused argument that " the Stat. 3 Henry VII extended not any way to this court, but that the lords authorized by that act may at all times in all places determine the matters therein spocified' (Callectanea Iuridica, ii. 10). The real point was that the star chamber, being the king's council, was not limited, like the common law-courts, to Westminster or term-time; but 3 Henry VU, c. 1, imposed no limit of time or place, did not refer to the council in the star chamber, and did not specify the acts done in the star chamber in Hudson's time. As to the personnel of the star chamber, the king or queen, but more normally the lord chancellor, welected it ad hoc on each important oceasion. Cf. Lellers and Papers, xvII. i. 746, the counoil in London to the council with the king, 'We ... appointed the Emperor's Ambessador to be here at the Sterre Chamber, yet we are ignorant of the King's pleasure what audience should be called'.

- Star chamber proceedings sometimes begin with a bill to the king and council complaining of the defendant's neglect or refusal to observe an injunction made by the chancellor (Trevelyan Papers, i. 129). The bills in Mrs. Temperley's Star Chamber Proc. (Somerset Rec. Soc. xxvii) are all addregsed to the king or king and council cxcept one (pp. 62-4) which belongs to the court of audience and is addressed to the archbishop.

There are a number of other acts authorizing the chancellor, treasurer, lord president, and lord privy geal to make administrative orders, but none of them mention the star chamber, though it is sometimes provided that offenders against these orders are to be tried in the star chamber (e.g. 25 Henry VIII, cc. 1, 2), just as offenders against the statute of Proclamations were to be tried there under 31 Henry VIIL, c. 8.

- See Leadam, Star Chamber Cases, ii, p. x. 'See below, p. 638, n. 1. 
by the act. It is simpler, in the total absence of evidence to the contrary, to assume that the act did not refer to the star chamber.

What, then, was its purport? Probably it should be interpreted in the light of another 'item' or act of the same statute of 1487, which appears as no. 26 on the roll of parliament and as no. 14 in the Petyt manuscript and printed statutes. Its title varies from 'Felony' in Caxton to more elaborate but inaccurate attempts to describe its object, which was to give the steward, treesurer, and comptroller of the king's household, or one of them, power to try, with a jury of twelve members of the household, and condemn for felony any members of the household, under the estate of lords, for confederacies, compassings, conspiracies, imaginations to destroy or murder the king, a lord of the realm, or king's counsellor; and the reason alleged for the act was the 'destruction of the kings and the near undoing of this realm' owing to quarrels among those in 'great authority, office, and of council with kings of this realm ', and to the fact that 'by the law of this land, if actual deeds be not had, there is no remedy for such false compassings', \&c. Henry VII's foes were of 'his own household. In the first fow days of his first parliament ${ }^{2}$ he had caused members of that household, peers, and commons solemnly in parliament to forswear retainers, maintenance, liveries, embraceries, riots, and unlawful assemblies ; and shortly afterwards, it is said, he had seen some of these very men indulging in the practices they had forsworn. The so-called Star Chamber Act of 1487 was intended to strike at the heart of the evil, its entrenchment in the king's household.

Now, it was difficult to strike by means of the council in the star chamber ; that council was a huge and unwieldy body which, moreover, contained some of the worst offenders. Hence the small but powerful personnel of the committee set up by that act : the chancellor, treasurer, lord privy seal, the two chief justices, and a bishop and a baron who would be nominated by the king or at his dictation. Hence, too, the privacy of the proceedings and absence of regular records. It was no part of Henry's design to advertise in a public court like the star chamber the misdemeanours of his household officials. The act was not intended to, and did not, deprive the council in the star chamber of its jurisdiction over similar offences committed outside the royal household, still less to determine the personnel of that council. Its object was to bring the more intimate offenders before a more intimate tribunal. No star chamber record has been found of the fine traditionally imposed on the Earl of Oxford for breaking the king's laws in the king's sight. Oxford was not a person whom Henry could afford

1 They were entitled of course to be tried by their peers for felony.

- Rot. Parl. vi. 287 ; my Henry VII, i. 26-7. 
to traduce in public. But the story is probably true, and it is also probable that the earl was fined by the committee set up by the act of $1487 .{ }^{1}$

It seems to follow that 3 Henry VII, c. 1, has no reference to the council in the star chamber except in so far as the committee it authorized contrined five king's counsellors and exercised over misdemeanours in the king's household a jurisdiction which the council exercised over the same offences elsewhere." How long this committee continued to act is uncertain; except in the statute-book there are few traces of its existence. In $1504^{3}$ parliament complains that so far as the punishment for giving liveries and keeping retainers is concerned 'lityll or nothing is or hath be doon', and proceeds in an elaborate act to enable either the chancellor in the star chamber, the king in his bench, or the council attendant to examine offenders by oath or otherwise, while the chancellor in the star chamber and the council attendant, provided three counsellors are present and that two of them are lords spiritual or temporal, are further enabled to proceed without any suit or information. None. of these tribunals corresponds with the committee of 1487. Possibly it had done its work and purged the king's household; more probably its inactivity after Morton's death in 1500 was due to the feebler hands of Deane and Warham, into which the Great Seal fell.

However that may be, the council in the star chamber continued to deal with all the misdemeanours mentioned in 3 Henry VII, c. 1, and many others as well, without regarding the prescriptions of that act. Hudson is specific in his assertion, ${ }^{5}$ which

1 The story has not been traced beyond Becon; but Henry VII certainly visited the earl for some dayt in 1498 (see Bentley, Excerpta Historica, p. 119). He may not, of course, have been fined in any court at all. One of the motives for the huge fines imposed in the star chamber was 'quoed terrorem magnatum', to induco offenders to compound with the king without being bronght intö court; and, according to Bacon, what Henry VII said to the earl pra "my attorney must opeak with you'.

- It might alternatively bo suggested that the committee of 1487 was a department of chancery. The chancellor exercised a common law as well as an equitable juris. diction, and since the king's bench was more given to dealing with treasons and folonies than with miedemeenours, the ohancellor may have stepped in to supply the deficiency. Certainly midemeanonrs were occasionally "reformed' in chancery as late as 1603 (Lembarde, Reports in Charcery, 1650, p. 30); bills were by 3 Henry VII, c. 1, to be put to the chancellor, and some, so addressed, survive (e.g. Laadam, Star Chamber Cases, ii. 118, 122, 142, 178, 184, 285). Stat. 33 Henry VIIJ, c. 1, moreover, refers to offenders alternately ' convicte by witneses taken before the Lorde Channcelor of Englande or by examination of witnesses or confession taken in the Starr Chamber at Westm. before the Kinges moat honorable counsell '

' 19 Henry VII, c. 18. This act was, however, to last during the king's life 'and no longer'.

- From Coke downmards it has been peraistenty stated that the star chamber derived its power to examine on anth from 3 Henry VII, c. 1. Apart from its doubtful asociation with the ster chamber, that act anys nothing about an asth.

- Collectanea Iuridica, ii. 23. 
may be based on the Liber Intrationum, that the star chamber ' did usually determine causes when neither treasurer, chancellor, nor privy seal were present, but sometimes the president of the council alone, ${ }^{1}$ and sometimes assisted by others of the council, above forty times in the 12 and 13 of Henry VII. And sometimes, when neither treasurer, president, chancellor, nor privy seal were present, other lords of the council sat for the determining causes.' Other evidence bears out this account; and it is very probable that Wolsey, soon after he became chancellor in December 1515, transferred to the star chamber the jurisdiction over household misdemeanours. There was nothing in the act of 1487 to prevent the council from hearing such cases in the star chamber, and Wolsey did not share Henry VII's reluctance to humiliate others of the king's servants in public. The more he did so, the more he magnified himself and his office, and he made the star chamber his megaphone and his press agency.

'And for your realm,' he wrote to Henry VIII,' ' our Lord be thanked, it was never in such peace nor tranquillity ; for sll this summer I have had neither of riot, felony, nor forcible entry, but that your laws be in every place indifferently ministered without leaning of any manner. Albeit, there hath lately been a fray betwixt Pygot, your serjeant, and Bir Andrew Windsor's servants for the seisin of a ward, whereto they both pretend titles; in the which one man was slain. I trust the nest term to learn them the law of the Star Chamber that they shall ware how from henceforth they shall redress their matter with their hands. They be both learned in the temporal law, and I doubt not good example shall ensue to see them learn the new law of the Star Chamber.'

It is difficult to say precisely what Wolsey meant by ' the new law of the Star Chamber'. There had been no new legislation, and Wolsey may merely be contrasting the temporal (= common) law with the civil law procedure of the star chamber. But he would hardly describe this as new, and the word refers more probably to Wolsey's new administration. The case between Piggott and Windsor, both of them eminent king's servants, was just the sort of case which would, if our interpretation of 3 Henry VII, c. 1 , is correct, have been dealt with under that act ; and it has long been thought that in Wolsey's time the committee of 1487 was reabsorbed into the whole council. When he was deprived of the Great Seal, Norfolk, treasurer, and Suffolk, the president-designate of the council, sat ' with the assent of other

\footnotetext{
1 These were probably poor men's suits, the 'court' of requests being a still undeveloped part of the council in the star chamber. We must also remember that Hudson regardo everything done by the council in the star chamber in Henry VIT's reign as star chamber business in the sense attached to the phrase under James I

- Letters and Papers, ii, app. 38. The letter is undated, but belongs probably to August 1518.
} 
lords ' to hear and determine cases in the star chamber for a week. 17-22 October, until Sir T. More took his seat as chancellor on the 24th. ${ }^{1}$ The act of 1529 may be a somewhat clumsy reaction to 1487, from Wolsey's predominance in favour of his two duoa] and seoular rivals. So far as star ohamber jurisdiction was concerned, 21 Henry VIII, c. 20, was even more abortive than 3 Henry VII, c. 1. The council in the star chamber continued to exercise its traditional jurisdiction in complete indifference to these statutes; and Sir Thomas Smith, who rightly remarks that the court began long before, and with equal justice that it 'took grest augmentation and authoritie' in Wolsey's time, has as little to say of the act of 1529 as of that of $1487 .^{8}$

We need not retail the conclusive proofs that during the fifteenth century the council sat in the star chamber, dealing there with judicial as well as political business and calling in the justices of the two benches, not as judges in the council, but as referees on points of law. ${ }^{3}$ It is more to our purpose to remark that, while it is necessary to point out that under the Lancastrians the council was also the star chamber, there is equal need to remember that under Henry VII the star chamber was also the council. The Liber Intrationum, for instance, is not, as it was treated by Elizabethan and Jacobean transcribers, merely a register of judicial procedings in the star chamber, but a general council book recording such matters as an order for the arrest of Robin of Redesdale, ${ }^{5}$ the conclusion of peace with Scotland and Spain, arrangements for succouring Calais by means of levies in Kent, Sussex, Suffolk, and Essex, and for the defence of the Scottish borders, discussion of proposed parliamentary legislation, and resolutions to execute Warwick and Perkin Warbeck and to dispatch and equip an expedition to Ireland.

1 Hall, Chron., p. 760 ; Cavendiah, Wolsey, 1852, pp. 158-61 ; Letters and Papers, Iv. 6025 .

T. Smith, De Republica Anglorum, ed. Alston, p. 117. Smith states (ibid. p. xiv) that he has sot forth the govornment of England as it stands "at this day the rrviii of March A mn 1685'.

Iaadam, Star Chamber, Cases ii, p. zii. The exchequer chamber, says Bacors (Henry VII, s. a. 1485), was the council chamber of the judgea.

- The surviving excerpte from it (e. g. Lansd. MS. 639, pp. 78, 92-5, 97, 114-18) are of precisely the ame cheracter as the Brit. Mus. MS8. from which Nicoles compiled much of what he called 'The Prooeedings and Ordinances of the Privy Council', and they noed to be treated as fragments of the council book of Henry VII. They do not appear to belong to the same category as the 'Kallenders' handed over to Sir F. Bacon as clerk of the star chamber in 1608 (Egerton Papers, Camden Soc., p. 428).

- A somewhat mysterious reference; seo Scofield, p. 7 n.

- Ibid. pp. 20-4. A similar jumblo, not of administrative and judicial, but of legislative and judicial business, can be of lords at the present time. No distinction is drawn between the proceedings of the howe as a logislative body and as a supreme court of appeal. The Liber Intrationkm

VOL. XXXVI. -NO. CXLVIII.

M m 
Even the fragmentary transcripts of the Liber which alone survive enable us, in spite of their misuse by their transcribers, to see that in Henry VII's reign council and star chamber were one body, or rather that the council was the body and the chamber its habitation. ${ }^{1}$

Nevertheless, a council attendant was emerging out of the general council in the star chamber; and if we had to identify the committee of 1487 with either, it would be with the council attendant rather than with the council in the star chamber. The act of 1504 does in fact give the two councils (if they can be called two councils instead of two bodies of counsel) concurrent powers of dealing with liveries and retaining without suit or information, while it does not mention the committeo of 1487 at all. Neither identification is, however, probable; and if logic compels us to identify the committee of 1487 either with counsel attendant or with counsel in the star chamber because it exercised jurisdiction in cases of riot, we shall have to deny the distinction between counsel attendant and counsel in the star chamber. The truth is that the distinction, though real, was only inchoste; it took the greater part of the sixteenth century to draw a firm line between the jurisdictions of the two, and even that discrimination was frustrated by the Stuarts when they practically eliminated the distinction of personnel between the privy council and the star chamber. In Elizabeth's reign, for instance, recognizances to appear before the star chamber were taken in the privy council; but in 1500 we have a recognizance to appear 'coram domino rege in consilio suo ubicunque fuerit' taken 'coram domino cancellario in camera stellata', as well as another recognizance in which the order is reversed; and in the latter case also the council attendant refers it, so far as title to lands was concerned, to the star chamber, but reserves it, so far as riot was involved, for its own consideration. ${ }^{3}$ According to later theory, the riot should have gone to the star chamber, ${ }^{4}$ and

\footnotetext{
similarly fails to distinguish the judicial and administrativo proceedings of the council in the star chamber; and even in Leadam's Select Cases (ii. 289-306) wo have printed in an eppendir such non-judicial documents as proclemetions againat forestallers and regraters, and certificetes of the shipment and discharge of victuals.

1 Nor was the star chamber the council's only habitation, even when it was trans. acting what we should call atar chamber business ; for 33 Henry VIII, c. l, gives J.P.'s and others power to bind over offenders against that act to appear before the king and council "in the aterred chamber at Westmynster or other place of their comen assemble in the terme next ensuying'.

'See an unpublished thesis by Miss Edna White, 'The Jurisdiction of the Privy Council', in the University of London Library; part of it was read, as the Alexander Prize Esagy, before the Royal Historical Society in June 1820.

- Sir Julius Caesar, Court of Requests, 1597, pp. 2, 26 (cf. Leadam, Requests, pp. rriiiv) : Scofield, p. 28.

- This was done, according to Caesar, two years later, in another caso cited by hin (ibid. p. 62).
} 
the rest of the case to the council, if, indeed, title to land was recognizable in either. ${ }^{1}$

The distinction in Henry VII 's reign between counsel attendant on the king and counsel in the star chamber was in fact simply a distinction between those counsellors who from time to time were selected to accompany the king on his progresses, and those who remained in London; and there was no permanence even in this personal differentiation. A counsellor attending the king one day or week might be a counsellor in the star chamber the next, and vice versa. Counsel with the king, whoever they might be, could 'move' or instruct counsel in the star chember simply because their orders were the king's; and the king being the source of all power, the nearer counsel were to the king the greater their authority. But there was as yet no constitutional discrimination between the jurisdiction of counsel attendant and counsel in the star chamber; and assuredly there was nothing done by the council in the star chamber which could not also be done 'coram rege et consilio suo ubicunque fuerit'. They were indeed one council, and this unity explains Mill's statement," which he did not quite understand himself, that "untyll the tyme of my last predicessor ${ }^{3}$ in a manner there was nothinge done either in the courte publiquely or in the inner Starr chamber privately ${ }^{5}$ but it passed under the hands of my predicessors and was entred in the bookes of entryes remayneing of recorde in the court in my custody'. The Liber Intrationum contains both political and judicial proceedings; it was kept in Henry VI's reign by Robert Rydon; and he was clerk of a single council which commonly sat for all its purposes (asve perhaps poor men's causes after 1493) in the star chamber.

Henry VII himself often sat in person with his council in the star chamber, ${ }^{b}$ and occasionally he withdrew from its cognizance

1 Hudeon (ii. 56) says ' the court did never take upon them to determine the right of inheritance, only took exsminations of it, referring the title to be discused by the judges and by them reported to the court; which was continued till 5 Elizabeth ... which course if it were now pursued, great titles would not have five verdicts on the one side and six on the other, and the land spent before the soit ended . . . and leses corruption used than now is : The council did, however, decide a dispute about inhoritance in 1533 (Letters and Papers, vi. 818).

- Hargrave MS. 216, p. 236, quoted by Mias Scofield, p. ïi.

- Thomas Marsh, clerk of the atar chamber from 6 Edward VI to 9 Elizabeth. Mill is exaggerating a little; his atatement is probsbly correct enough down to 1540 , when the clerka of the privy council began their own perticular regieter, but not down to 1551. The clerk of the atar chamber did, indeed, continue to attend oven the privy conncil during term-time down to the end of the sixteenth contury as a sort of liaison officer (Scofield, p. 36, n. 1), but he hed no sort of control over the clertes of the privy council.

- i. e. of star chsmber.

- The privy council often sat in the inner star chamber, where there was a " counciltable' (Acts of the Priv. Coun., xiii. 412, xix. 383).

- Fourteen occasions are noted in the fragmentary extracts from the Liber Intrationum (Scofield, pp. 6-8, 16-24). 
cases for his own decision, even cases of riot. ${ }^{1}$ But as early as 1494, by steps which have not been traced, the council in the star chamber had come to be regarded as the chancellor's court. 'Ther hath be', writes one in November of that year, 'so gret cownsell for the kynges maters that my lord chawnsler kept not the ster chawmber thys viii days but one day at London.' ${ }^{2}$ Henry VIII in his earlier years was not so assiduous as his father, ${ }^{3}$ and when in middle life he devoted himself to government, it was to matters of high politics rather than to the administration of law and order ; and these were better treated in a privy council than in the public court of star chamber. Meanwhile Wolsey had made the star chamber famous throughout the land by its ' new law' or unprecedented vigour of administration. There he sat in his estate and held his court, while the king was left with an almost insignificant council attendant; and the outward manifestation of Wolsey's impending fall occurred when in October 1529 he 'came into Westminster hall with all his trayne the first day of the Terme; but none of the kynges seruantes would go before, as they were wont to do, and so he sat in the chauncery, but not in the starre chamber, for all the lordes and other the kynges counsaill were gone to Wynsore to the kyng '."

But Wolsey's energy had attracted so much business to the star chamber as to make it unmanageable; and in 8 Henry VIII (21 April 1516-20 April 1517) he 'ordeyned by the kynges commission diuerse under-courtes to here complaintes by bill of poore people'.5 One was kept in the white hall, one before the king's almoner (Stokesley), a third in the lord treasurer's chamber beside the star chamber, and the fourth at the Rolls. The experiment, says Hall, had only a transient success, partly owing to the defects of the subordinate judges; and in 1525-6 Wolsey embarked upon a different and far more extensive policy of decentralization. Part of it was possibly due to the demands of the king to be better provided with counsel, which led to the provisions in the Eltham ordinances. The rest was the delegation to provincial councils of all star chamber cases arising within their spheres of jurisdiction, notably the Lady Mary's council for Wales and its marches

1 Scofield, p. 6 : "the L Lisle and Brightmere and others dismist of the riott, for that the kinge himselfe would heare the same, as his atturney made certifficate'. Probably this was to induce the offenders to compound.

- Pasion Letters, iii. 385. The chancellor became almost an autocrat in the council in the star chamber, whereas he had no such pre-eminence in the council attendant, so that Wolsey had personal as rell as public reasons for magnifying the former.

2 Oocasionally he sat in the star chamber; cf. Hall, Chron. pp. 599-600.

- Hall, p. 760.

- Ibid. p. 585 ; Letters and Papers, iii. 571 (placed under 1519 by Brewrer, but probably belongs to 1517); Fiddes, Life of Wolsey, p. 532; Hudson, Collectanea Iuridica, ii. 219. 
and the Duke of Richmond's council for northern parts. ${ }^{1}$ Sir Thomas Elyot's letter, quoted in my previous article, ${ }^{2}$ complaining that this delegation deprived him of his living as clerk of the star chamber, is the most striking testimony to the effect of the policy ; and it has even been said that after Wolsey's fall 'we seldom hear of the star chamber' in Henry VIII's reign. This assertion is hardly justified, and there are numerous complaints, especially from Wales and its marches, that the delegation was not observed, but that cases were continually being called up to Westminster.

Nevertheless the council in the star chamber never recovered the position it had held under Wolsey, and its gradual subordination to the privy council was due to deeper causes than the disappearance of Wolsey's personality or the delegation of functions to provincial councils. Fundamentally it was due to the circumstance that the problem of maintaining domestic law and order was becoming less dominant, partly becsuse the star chamber had done its best work, and partly because other problems of external and ecclesiastical politics emerged which required a different sort of council from that in the star chamber to deal with them. This counter-attraction may have been partly responsible for the legislative proposals to relieve all counsellors except the chancellor from the necessity of attending the star chamber." The chancellor himself was often distracted betwoen the law and politics. Probably Wolsey's schemes of 1516-17 and 1525-6 were partly due to a wish for more time to spend on foreign afairs. Sir Thomas More was freer to devote himself to the law, and Audley, his successor, had little political aptitude or ambition. No later chancellor combined like Wolsey the direction of the Great Seal with that of foreign policy. Wriothesley may have aspired to the part, and he had conspicuous ability ; but when, early in Edward VI's reign, he commissioned subordinates to exercise his cancellarial duties in order to find more time for politics, his opponents were able to precipitate his fall. ${ }^{5}$ His successors Rich and Goodrich were politically unimportant. Bishop Gardiner recovered some shreds of Wolsey's power, but Heath resembled Warham rather than Wolsey, and Elizabeth's lord keepers and lord chancellors were lawyers completely over-

1 R. R. Reid, Council in the North, 1921 ; C. A. J. Skeel, Council of Wates and ite Marches, 1904.

- Above, p. 360.

John Bruce in Archaeologia, 1xv. 377-8.

- The chancellor was paid $\$ 200$ s year extra for this duty. His total remuneration, zccording to Queen Elizabeth's Annual Bxpence (Boc. of Antiquaries), p. 241, came to $f 1,047$ a year (ct. Letters and Papers, Iv. 6079, xIx. i. 610 [41]). The lord privy ses] had $\$ 365$ a year out of the customs of London, Bristol, Poole, Plymouth, Fowey, \&c. (Letters and Papers, III. 3176, IV. 6163; for details see ibid. IVI. 1251 [7]).

- See my England under Protector Somerset, 1800, pp. 31-3. 
shadowed by her statesmen. So, too, the politicians were gradually drafted into a privy council, from which the two chief justices were as a rule excluded, while they remained an integral part of the council in the star chamber. The major part of the history of the council under the Tudors is bound up with the growing specialization of functions between the executive and the judicature.

We have already traced that specialization so far as it is reflected in the elaboration of distinct clerkships for the council in the star chamber and the privy council ; ${ }^{1}$ and the subsequent history of the clerkship of the council in the star chamber can be briefly indicated in a list of names. ${ }^{2}$ But it is necessary to say something about the position and personnel of the old council in the star chamber after its political importance had departed to the privy council. Traditionally and technically the clerk of the star chamber remained the senior clerk of the council, and the counoil in the star chamber was the superior council. Burghley is even quoted by Mill ${ }^{3}$ as saying openly in the star chamber that 'the same court was the councell of state of this Realme and the clerke thereof the onely clerke of the Councell of State and that there was noe other clerke of the Queenes Councell of State ... and that the others were clerkes of the Privy Councell attendant upon her Mates Royall person '. Hawarde also quotes Burghley as saying that the star chamber was 'a court of state',' and Hudson slightingly contrasts this public court with the private board of the privy council.s He speaks of

Above, pp. 345-51. The precedence of the clerk of the star chember as 'the first clert of the council in place' wes, according to Hudson (Collecianea Inridica, ii. 37) definitaly established by the heralds in 1688.

T. Marsh sucoeded T. Eden in $\theta$ Elirsbeth and was sucoeded by W. Mill in 1572-3. Mill died on 16 July 1608 , when $F$. Becon succeded but exercised his functions by a deputy, Edward Jones (Hawarde, Reports, p. 360). A part reversion had alreedy been granted on 26 November 1607 and confirmed on $17 \mathrm{Jaly} 1609$ to (Sir) Humphroy May (Cal. of Slate Papers, Dom, 1603-10, pp. 384, 630); and Hudson (p. 39) says that "now [1621 ?] May and Mr. Morloy hold it jointly and executo the same by deputy'. Possibly this was Iseac Cotton, who dedicates his excellent account of the star chamber to Sir Hum phroy May and his brother Thomas, probably the father of the poet and historian of the long parliement. Cotton's treatise is extant in two Brit. Mus. manuscripts, Stowe 418 and Lansdowne 639. The former is the better and dates from 1618; the latter dates from 1622, and is used by Bruce in Archacologia, xxv. 379. Other subordinate clerks whose nemes aro mentioned are George Christopher, Thomas Mynat, Henry Parker, and Hudson himself (Scofield, pp. iv n., xiv, rviii, 14, 63 n., 67 n., 82 ; Egerton Papers (Camden Soc.), pp. 427-8; Bridgewaler MS8. (Hist. MSS. Comm.), p. 165 ; Lambarde, Archeion, pp. 192-3 ; Hudson, pp. 2, 39; Hawarde's Reports, pp. 1, 2, 38, 63, 94).

- Scofield, p. 62. The distinction between 'our Privie Councell' and 'our counsell of eatate' was as old es Edward VI's reign (Lit. Remains of Edward VI, p. 496; Egerton Papers, p. 24). Elizabeth also styles Mill 'clerk of our counceill' and 'our chief clarke' (Egerton Papera, pp. 316-17).

- Ed. Baildon, p. 15 ; ef. Nicolas, iv. 63 ; Hadson, pp. 4-5, 10, 50.

- Callectanea Iuridica, ii. 62. 
James I sitting there 'five continual days in a chair of state elevated above the table about which his lords sat ' ${ }^{1}$ and that king characteristically enough preened himself in the star chamber much as Henry VIII preened himself in the high court of parliament. ${ }^{2}$

The medieval king's council, therefore, continued its existence under the Elizabethan disguise of the court of star chamber. As Professor Baldwin has remarked, 'while other branches of the modern council were soon formed, it is particularly the court of star chamber which is to be regarded as the institutional continuation of the original medieval council.' 3 The change in terminology from ' council in the star chamber' to 'court of star chamber' made of course not an atom of difference to the personnel or to the jurisdiction of the council or court. It was merely a popular verbal alteration, and so long as the 'court' existed its legal designation was coram consilio. The change has, however, on the one hand obscured the historical continuity of the king's council and the star chamber, and on the other illustrated an important development in the history of political and constitutional ideas. The propriety, if not the necessity, of drawing a line in theory and in practice between executive and judicial functions took more and more hold of men's minds, and the two general words, council and court, were gradually given specific meanings in accordance with this differentiation. Council was to be reserved for the executive, court for the judicial, body. Thus we find that about the middle of the century the council in the white hall comes to be called the Court of Requests, ${ }^{4}$ and, a little later perhaps, the council in the star chamber to be known as the court of star chamber. The indeterminate stage is well represented by 5 Eliz., o. 9 , which speaks of the chancellor and others of the council determining matters in the court at Westminster commonly called the star chamber.

This continuity bequeathed to the court of star chamber some ambiguity as to its composition. The Crown had before Elizabeth's reign established its claim to be the sole arbiter of the personnel of the privy council, while the peers had established theirs to be hereditary counsellors of the Crown in parliament. What was

- Collectarea Irridica, ii. p. 9.

- Compare James I's apeech in the atar chamber, 20 June 1616 (Political Works ed. McIlwain, pp. 328-46), with Henry VIII's speech in partiament in 1042 (Holinshed. iii. 956 ; Letters and Papers, xrii, Pp. iv, 107).

The King's Council, p. 442.

- Public Record Office Liat of Cases in the Court of Requeste, pref.; Leadsm calls the term 'court of requests' "an anachronistic but convenient name' (p. Iviii; cf. pp. riv-ry). The seme is true of the court of star chamber and of the 'court' of high commission; bat the atmost confusion is caused in constitutional history by assuming that constitutional terms had a definite meaning $a b$ initio, before the institu. tions themselves had developed. 
to happen with regard to the lords of the council in the star shamber, where an act of Henry (31 Henry VIII, c..10, § 10) had ordained that they were to sit in the same order as in parliament ? As late as 22 June 1604, Lord Zouche, president of the council in Wales, affirmed in the star chamber that 'he was allwayes of opinion that enery Baron of Englaunde mighte take place and sitte in this cowrte' ; and the lord chencellor refused to express an opinion, saying that it was not a matter for the court but for the earl marshal to decide. ${ }^{1}$ No decision is reported, but the question was much debated. There is, however, little doubt as to the practice in Elizabeth's reign. Although Sir Thomas Smith includes in the personnel of the court 'the Lordes and others of the privie counsell, so many as will, and other Lordes and Barons which be not of the Privie Counsell and be in the towne',? Henry VIII had certainly at times determined ' what the audience should be'; and Camden, writing in 1586, twenty-one years after Smith, expresses Elizabeth's practice more accurately when he defines the court as consisting of 'omnes consiliarii status tam ecclesiastici quam laici, et ex Parliamenti Baronibus illi quos princeps advocabit' ${ }^{3}$ Mill quotes his father to the effect that 'noe man should sitt in the courte but if hee were sworne. of the Councell ', and confusion has been caused by the assumption that council in the elder Mill's time meant the privy council. The star chamber being the council in the star chamber, it followed that no one could sit without being sworn. ${ }^{5}$ James I himself says that the court consists of "four sorts of persons : the first two are privie counsellours and iudges . . . the other two sorts are peeres of the realme and bishops '; ${ }^{\circ}$ but assuredly he did not mean to imply that a peer or a bishop as such could claim to sit in the star chamber. In Elizabeth's reign any privy councillor could sit in the star chamber ; the rest of the court was constituted from time to time of such peers, bishops, and judges as the Crown or the chancellor chose to summon.?

This regular practice was an effective denial of the claim of barons to sit as consiliarii nati; and, as the old council fell into

1 Hewardo, Reports, od. Belldon, p. 171; cf. Hadson, if. 24-6; Mill in Hargraw MB. 216, p. 202 ; Boofield, pp. 12-13.

- De Republica, ed Aloton, p. 116.

- Britarsia, 1586, p. 63.

- Hergravo M8 210, p. 202 ; Bcofield, p. 13 ; Leadam, Star Chamber Casen, ii, pp. rxwiii-ix; Hudeon, ii. 24-6.

- Members of the old council were sworn; if, later on, they wore admitted to the privy council, they were eworn again. The form of the old comnoil outh is given in Rot. Parl. v. 407. For instances of this double svearing seo Letters and Papers, vii. 1525, vilf. 225 ; Nicoles, vii. $51,57-8$.

- Palitical Torta, p. 336.

- CA. Rushworth, il. 474: the chancellor 'st his own discrotion commandeth the Chief Jurtice or any other judge to sit there at his pleasure'; and Hudeon, ii. 25 : 'I doubt not but that it reeteth in the king' plearuro to reatrain any man trom that table, as well as he maj any of his council from the board.' 
abeyance, the Crown's power of varying the personnel of the court for each occasion increased. It is certain that only some of the scores of counsellors of Henry VII and Henry VIII sat in the star chamber, and that Wolsey and Henry VIII on occasion made the selection. In Elizabeth's reign the rank and description of councillor, apart from that of privy councillor, tended to die out, and was not even applied to peers. ${ }^{1}$ But she recognized the desirability of calling others than privy councillors to sit in the star ohamber, especially in important cases, and adopted the practice of calling them by commission, a term which emphasized, as againgt consiliarius natus, the royal derivation of the authority in virtue of which the commissioners sat. So we find persons appointed to try Secretary Davison in the star chamber 'by virtue of a commisgion to them directed ' $;{ }^{3}$ another case in February 1697 is tried there "by the Lord Keeper and the rest of her Majesty's commisaioners '; ' in May 1601 'these gentlemen hereunder mentioned were called at the starr chamber before theire Lordshippes by vertue of her Majesty's commission' ; ${ }^{5}$ and in February 1591 a peerage case is ordered to be 'heard at the star chamber by such of their Lordships and others as are therunto appointed by her Majesty'. The Bame terminology was used in the court of requests; on 9 March 1552 Edward VI appointed eight 'speciall commissioners' to hear all the sutes and requestes aforesaide', and although only one was a privy councillor, the appearances before them are coram consilio.?

The records of the star chamber under Elizabeth and James I leave no doubt that others besides privy councillors sat in the court. In Davison's case ten out of the thirteen members of the court were not privy councillors. ${ }^{8}$ This was a quite unusual proportion, due no doubt to the delicacy of privy councillors condemning a colleague in the star chamber for what they had ordered him to do at the council board. At the well-known trial on 15 November 1581 of Lord Vaux and others on the charge of harbouring Edmund Campion ${ }^{2}$ three, besides the professional lawyers,

'Lorde' Jownals, i. $\mathbf{5 7 6 .}$

- There are no vixteenth-century dooumenta properly called 'commissions'. Commision is a delegation of power, not the instrument by which it is delegeted; and power meg be delegeted by lotters petent or oloee, privg ceels, warrants, writs, or oven wond of month (at. Cowall, Interpreter; Bgarton Popers, pp. 24, 319-21 ; Leadem, Court of Requests, p. bociili ; Lit Remains of Edword VI, p. 499).

- Nicoles, Life of Dovion, pp. $803,930$.

- Acts of Prio. Coun, 1696-7, p. 478.

- Ibid, 1500-1, p. 251.

Ibid, 1600-1, pp. 366-7.

Public Record Office Liat of Cases, pref.

Nicoles, loc. cic, prints two manusoripte, both of which give the same personnel ; wo does Camden, Amrales, ii. 640 ; Hodson sleo discusen the cave (Callectarea Ituridica, ii. 25)

- There is a foll report of this can in Harl. M8. 859, foa. 44-61, and a whorter one in

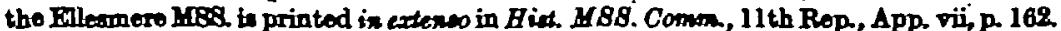
Bruoe printed the Hart. MB. in Arehacologia, xx. 80-110. The Privy Council Ropdater 
were not privy councillors, Lords Buckhurst, Cromwell, and Norris.' At Arundel's trial in the star chamber on 17 May 1586 there were present 'the judges of every Bench, seving the Lord Chief Justice of England who was sick. Mr. Justice Periam gave judgement, with his opinion, the first, whereto all the rest did consent '. ${ }^{8}$ At the end of Elizabeth's reign the bishops of London, Winchester, and Worcester were occasionally present, ${ }^{3}$ although not privy councillors, and the queen's almoner regularly sat in the court to claim deodands and goods of felomes de se." An examination of the list of attendances given in Mr. Baildon's edition of Hawarde's Reports (pp. lxxv-lxxxv) shows that the attendance of others than privy councillors continued till 1609 , when his reports cease. James I's mention of privy councillors as only one of the four sorts of persons composing the court contradicts any other supposition as late as 1616 ; and Rushworth carries on the practice to 1640. All the authorities are in fact agreed, though it is doubtless true, as Hudson says, that the attendance was ' much lessened since the barons and earls, not being privy councillors, have forborne their attendance '.'

The star chamber abolished by the long parliament was not therefore a court created in 1487 and resting on 3 Henry VII, c. 1 , but a jurisdiction appertaining to the king's medieval council; and a realization of this fact helps us to answer the much-vexed question what, if any, was the statutory authority for the vague and extensive jurisdiction exercised in the star chamber. The doubt arises from speaking of the star chamber when we should speak of the king's council, and the question is what was the statutory authority upon which that council's

is wanting from 1582-6, but Buckhurst's admiosion in Fobruery $1585-6$ is mentioned by Walainghem in For. Cal, 1585-6, p. 353, and also in Rulland MSS. (Hist. MSS. Comm.) i. 189. Cromwell and Norris were never ptivy councillors.

1 The account in Harl. MS. is particularly interesting as showing that in the star chamber members voted as they did in treason trials before the house of lords, i.e. beginning with the junior member, the chancellor or lord keeper voting last. This rule of the council in the otar chamber wa formally adopted in 1627 for the privy council and was reaffirmed in 1878 to regulate procedings in its judioial committee (Anson, Law and Cuolom, ed. 1808, II. ii. 293-4). 'No publication,' continues the order in council, "is afterwards to be made by any man how the particular voices and opinions went'; and this rale spplies or applied also to the cabinet committee of the privy

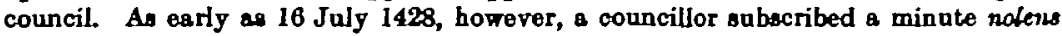
volo (Nicolas, iii. 312). All votes were equal, except passibly that of the chancellor; it was even maintained that he could give sentence by himself (Hawarde, Reports, pp. 5-6). In this respect as in so many others the judges' interpretation of the act of 1487 that all members of that committeo except the chancellor, treasurer, and lord privy meal, were merely assistants and not judges was not regarded as binding the star chamber; and no distinction was there made between the privy councillors and other membera. - Lodge, Illustrations, ii. 286.

- Egerton Papers, p. 322 ; Hudson, ii. 19, 56, 137; Leadam, Star Chamber Cases, i, p. xxrix; Howarde, Reports, passim.

- Hudson, ii. 57.

- Ibid. ii. 36. 
jurisdiction rested. That question is easier to answer. Repeatedly during the last half of the fourteenth and first half of the fifteenth centuries parliament delegated to the council statutory authority to hear and determine, calling to them the justices and others skilled in the law, ${ }^{1}$ parliamentary petitions with which parliament had had no time to deal, and even to enrol its decisions on the parliament roll. The phraseology of one of the later of these acts of parliament, ${ }^{2}$ passed in 1427, lays down the personnel of which the council in the star chamber always consisted; and it was actually in the star chamber that on 15 June 1427 the lords of the council are recorded in the rolls of parliament as having undertaken the task which parliament had committed to their charge. Nor were these matters of common law, but matters with which the star chamber commonly dealt; for no one had need for a petition in parliament if remedy was available at common law.

The same continuity helps us to understand the terms in which not only Mill and Hudson, Bacon and James I, but Smith and Lambarde, Camden and Coke, speak of the court of star chamber. When Smith writes of the suitor there 'seeing as it were the majesty of the whole realm before him ' ; 3 when Lambarde remarks that it ' hath obtained that dignity to bear a name above all others' ; 4 when Camden says ' si vetustatem spectemus, est antiquissima, si dignitatem, honoratissima' $;^{5}$ and Coke declare that 'it is the most honourable Court (our Parliament excepted) that is in the Christian world ', they were not referring to a mushroom growth, nor to a private committee set up in 1487 to deal with household offences, but to a king's council which was older than parliament itself ; and when the long parliament 'abolished' the star chamber in 1641, it only out out the dying wood, leaving, perhaps by some unforeseen accident, the original root to develop in the fullness of time a jurisdiction which under the ancient name of 'the Board ' embraces appeals from a world-wide empire.

A. F. Pounard.

I Beo my Evolution of Parliandent, pp. 128-32.

- Rat. Parl. iv. 334 : 'Pleces an Roi nte soverain 87 conniderer, comme plusour Petitions ount estes baflles ot exhibites a vte trea noble hatesse p les communes de ceet proent Partoment, pur ent evoir coveneblo remodie, ot unquore nient determinees, d'ardeiner p advye des Beigárs Enpirituelx ot Temporelx, ot esent des Communes avenutdits, que les dites Potitions purront estro deliveres a les Boighin do vifo tros abge conseill, lesquenx appellex a oux les Justicen et antres gents aprises en vfo loy, ai bosoigne $y$ soit, ajant posir $p$ enotorite da dit Perlement, pentro oy et lo Festo del Nativito du Soint John Baptisto proahein \& venir, d'oier et terminer les dits Petitions; ot que yoelle ensi tormines do l'advys ot essent suedits purront entro enectes, enarollez, et mys do recorde en lo rollo do mesmo vio Partement.

Io Roi le root

Et pain, o'cut a voir, lo xv jour de Jayn . . en precence des plasobrs Boigürs da conseil nostro dit Sr lo Roi . . . esteents on le Bterro chambre do Westif? ...'

- De Republica, od: Alton, p. 116. -Archeiom, 1635, p. 175.

- Brilannia, ed. 1600, p. 141.

- Pourtir Inotitute, a 5. 